\title{
The antigenicity of $\boldsymbol{\gamma}$-irradiated vaccinia virus
}

\author{
By COLIN KAPLAN \\ Smallpox Vaccine Unit, Lister Institute of Preventive Medicine, \\ Elstree, Hertfordshire, England
}

(Received 24 June 1960)

Inactivation of vaccinia virus by heat and many chemicals destroys its protective antigenicity. However, Collier, McClean \& Vallet (1955) preserved measurable immunogenicity in suspensions of vaccinia virus inactivated by ultra-violet light in a Habel-Sockrider apparatus. Because of this we thought it worthwhile to investigate the effects of ionizing radiations on the protective antigenicity of the virus.

\section{METHODS}

Virus

The Lister Institute vaccine strain was used. Suspensions of virus from sheep vaccinial pulp were partially purified by one cycle of differential centrifugation and diluted in phosphate and citric acid buffer, $\mathrm{pH} 7 \cdot 2,0 \cdot 004 \mathrm{M}$ phosphate to a titre of about $10^{7}$ pock-forming units per millilitre (p.u./ml.) before irradiation. Dried virus samples were prepared by freeze-drying in $5 \%$ peptone (Collier, 1955). The vaccines were dried in a centrifugal freeze-drying machine, and the dry material was in the form of wedges in $0.5 \mathrm{ml}$. ampoules. The single batch of dried rabbit virus used had an initial titre of $4 \cdot 1 \times 10^{8}$ p.u. $/ \mathrm{ml}$.

\section{Irradiation}

The virus preparations were irradiated by the Technological Irradiation Group of the Isotope Research Division of the Atomic Energy Authority. We are indebted to the Group for the irradiations and for the following information. Exposures were made to $\gamma$-rays emitted by cobalt- 60 sources enclosed within concrete shields. During the course of the experiments different sources were used, and dose rates and conditions of exposure varied from $4 \times 10^{5} \mathrm{rad} . / \mathrm{hr} .( \pm 10 \%)$ at c. $45^{\circ} \mathrm{C}$. to $1.08 \times 10^{5} \mathrm{rad} . / \mathrm{hr}$. $( \pm 5 \%)$ at $15^{\circ} \mathrm{C}$. Total doses were determined by a ferrous sulphate technique. As a result of handling, the dried wedges were generally broken into crumbs of peptone in the ampoules. We cannot, therefore, give any data of sample dimensions relative to beam dimensions.

\section{Infectivity titrations}

These were done by pock counts on chick embryo chorio-allantoic membranes (Westwood, Phipps \& Boulter, 1957). Dilutions were made in McIlvaine's phosphate + citric acid buffer, $\mathrm{pH} 7 \cdot 2,0 \cdot 004 \mathrm{M}$ phosphate. Five embryos were inoculated with each dilution tested. To establish complete inactivation of 
infectivity, embryos were inoculated with undiluted material; more than 5 were used when possible. When the results of inspection after 2 days incubation at $36^{\circ} \mathrm{C}$. were doubtful, the membranes-aseptically harvested-were extracted in buffer and subinoculated to fresh embryos. In one experiment irradiated virus was concentrated by centrifugation before inoculation.

\section{Antigenicity tests}

Each inactivated preparation was tested in five rabbits. The animals were bled for normal serum before inoculation and then given two subcutaneous injections, each of $1 \mathrm{ml}$., of the test suspensions at an interval of 2 weeks. Two weeks after the second injection the animals were bled again, and challenged by cutaneous scarification with a potent, glycerolated smallpox vaccine known to produce at least a semiconfluent lesion at a dilution of $10^{-4}$ in normal rabbits. The lesions were inspected daily from the third day and scored on the fifth day. In normal rabbits vaccinial lesions generally show no signs of scabbing until the ninth or tenth day. Immunized animals, however, often develop lesions which fade precociously or become black and necrotic at the centre-the so-called abortive lesions. These were recorded in our test rabbits.

Virus neutralizing antibody in the serum samples was titrated by mixing serum dilutions with a constant challenge dose of virus, ten times the minimal amount necessary to produce a confluent lesion on a normal rabbit. The virus and serum mixtures were incubated for $1 \mathrm{hr}$. at $22^{\circ} \mathrm{C}$. and then inoculated by scarification of normal rabbits. The neutralizing titre of the serum was taken as the highest dilution which reduced the response to not more than ten vesicles. Antibody titrations by pock inhibition on the chick embryo chorio-allantois were done as described by Boulter (1957).

\section{RESULTS}

When virus, suspended in liquid, was irradiated in a Co- 60 source the temperature reached $45^{\circ} \mathrm{C}$. after $5 \mathrm{hr}$. The dose rate was such that, at the maximum dose used, the virus suspensions were heated at $45^{\circ} \mathrm{C}$. for $8 \mathrm{hr}$. Because of this, and also because of some irregular results thought to be due to changes in the suspensions of virus while travelling in the post, dried virus was used for several experiments (Tables 1-3; fig. 1).

The results of five experiments with dried virus were consistent, but were irregular at the higher radiation doses, from the point where the rate curve flattens (Table 3; fig. 1). Other ampoules of virus treated at these doses were tested several months later. The virus titres were usually about equal to those in ampoules tested immediately after irradiation, but in occasional ampoules no virus was detected. Because of the apparent stability of a minute fraction of the dried virus, even when exposed to doses of $\gamma$-rays as high as $11 \times 10^{6} \mathrm{rad}$., tests of these preparations for residual immunogenicity of inactivated virus were clearly precluded. A few suspensions of virus were irradiated at several doses in a Co-60 source in which temperatures could be held at less than $20^{\circ} \mathrm{C}$. The preparations were all small samples of elementary body suspensions (EBS) partially purified for smallpox 
Table 1. Inactivation of dried vaccine by $\gamma$-rays

$\begin{array}{cc}\begin{array}{c}\text { Dose } \\ \text { (Mrad.) }\end{array} & \begin{array}{c}\text { Surviving } \\ \text { virus (p.u./ml.)* }\end{array} \\ 0 & 3 \times 10^{8} \\ 3 \cdot 5 & \sim 2 \times 10^{3} \\ 4 \cdot 0 & 3.5 \times 10^{2} \\ 4 \cdot 5 & 2 \cdot 6 \times 10^{2} \\ 5 \cdot 0 & 2 \cdot 0 \\ 5 \cdot 5 & 6 \cdot 0\end{array}$

* Titrated on chick chorio-allantoic membranes.

Table 2. Inactivation of dried vaccinia virus by $\gamma$-rays

$\begin{array}{ccccc}\begin{array}{c}\text { Dose } \\ \text { (Mrad.) }\end{array} & \begin{array}{c}\text { Surviving } \\ \text { virus } \\ \text { (p.u./ml.) }\end{array} & \log V_{0} / V & \begin{array}{c}\text { Surviving } \\ \text { virus } \\ \text { (p.u./ml.) }\end{array} & \log V_{0} / V \\ 0 & 1 \cdot 3 \times 10^{7} & 0 & 1 \cdot 4 \times 10^{7} & 0 \\ 1 & 2 \cdot 3 \times 10^{4} & 2 \cdot 76 & 1 \cdot 3 \times 10^{4} & 3.05 \\ 2 & 4 \cdot 4 \times 10^{3} & 3 \cdot 47 & 8 \cdot 0 \times 10^{2} & 4 \cdot 25 \\ 3 & 3.9 \times 10^{2} & 4.53 & 47 & 5 \cdot 47 \\ 4 & 60 & 5 \cdot 34 & 15 & 5 \cdot 97 \\ 5 & 2 & 6 \cdot 82 & 2 & 6 \cdot 85 \\ 6 & 1 & 7 \cdot 12 & * & -\end{array}$

$V_{0}=$ initial virus titre; $V=$ titre at any specified irradiation dose.

* No pocks on titration membranes. Passage of membrane extracts + ve.

Table 3. Inactivation of dried vaccinia virus by $\gamma$-rays

\begin{tabular}{|c|c|c|c|c|c|c|}
\hline \multirow[b]{2}{*}{$\begin{array}{c}\text { Dose } \\
\text { (Mrad.) }\end{array}$} & \multicolumn{2}{|c|}{1} & \multicolumn{2}{|c|}{2} & \multicolumn{2}{|c|}{3} \\
\hline & $\begin{array}{c}\text { Surviving } \\
\text { virus } \\
\text { (p.u./ml.) }\end{array}$ & $\begin{array}{l}\log \\
V_{0} / V\end{array}$ & $\begin{array}{c}\text { Surviving } \\
\text { virus } \\
\text { (p.u./ml.) }\end{array}$ & $\begin{array}{l}\log \\
V_{0} / V\end{array}$ & $\begin{array}{c}\text { Surviving } \\
\text { virus } \\
\text { (p.u./ml.) }\end{array}$ & $\begin{array}{l}\log \\
V_{0} / V\end{array}$ \\
\hline 0 & $3 \times 10^{9}$ & 0 & $1.2 \times 10^{7}$ & 0 & $4 \cdot 1 \times 10^{8}$ & 0 \\
\hline 0.58 & $6 \times 10^{5}$ & $1 \cdot 7$ & $1.8 \times 10^{5}$ & $1 \cdot 83$ & $8.4 \times 10^{6}$ & $1 \cdot 7$ \\
\hline $1 \cdot 74$ & $1.9 \times 10^{4}$ & $3 \cdot 19$ & $2.8 \times 10^{3}$ & $3 \cdot 63$ & $1.5 \times 10^{5}$ & $2 \cdot 44$ \\
\hline $2 \cdot 32$ & $2.7 \times 10^{3}$ & $4 \cdot 05$ & $1.9 \times 10^{3}$ & $3 \cdot 80$ & $7 \cdot 6 \times 10^{4}$ & $3 \cdot 74$ \\
\hline $3 \cdot 48$ & 81 & $5 \cdot 57$ & $8 \cdot 8$ & $6 \cdot 13$ & $*$ & - \\
\hline $5 \cdot 22$ & 5 & $6 \cdot 78$ & 0 & $>7.08$ & $*$ & - \\
\hline $5 \cdot 8$ & $0 \dagger$ & $>7 \cdot 48$ & $2 \cdot 0$ & $6 \cdot 78$ & * & - \\
\hline $6 \cdot 96$ & 4 & $6 \cdot 88$ & $3 \cdot 8$ & $6 \cdot 50$ & * & - \\
\hline $8 \cdot 12$ & $>15$ & $<6 \cdot 30$ & 0 & $>7.08$ & 30 & $7 \cdot 14$ \\
\hline $9 \cdot 28$ & $8 \cdot 7$ & $6 \cdot 54$ & $2 \cdot 0$ & $6 \cdot 78$ & 36 & $7 \cdot 07$ \\
\hline $11 \cdot 6$ & $15 \ddagger$ & $6 \cdot 30$ & $2 \cdot 5$ & $6 \cdot 68$ & 28 & $7 \cdot 17$ \\
\hline
\end{tabular}

1 and 2, preparations of vaccine virus; 3 , highly purified rabbit virus.

$\dagger$ Fresh ampoule retested: 4 p.u. $/ \mathrm{ml}$.; $\log V_{0} / V=6 \cdot 88$.

$\ddagger 2$ ampoules retested: 2 p.u. $/ \mathrm{ml} ; 3$ p.u. $/ \mathrm{ml}$.

* Not enough embryos for these samples to be titrated. Whole sample reconstituted to 0.4 or $0.6 \mathrm{ml}$. and inoculated to two or three embryos. Virus was present in all. 
vaccine production, diluted to a titre of about $10^{7} \mathrm{p} . \mathrm{u} . / \mathrm{ml}$. Two suspensions were completely inactivated by $10^{6} \mathrm{rad}$. and were not immunogenic. Two further samples, EBS 50/58, inactivated by $6 \times 10^{5} \mathrm{rad}$., and EBS 57/58, inactivated by

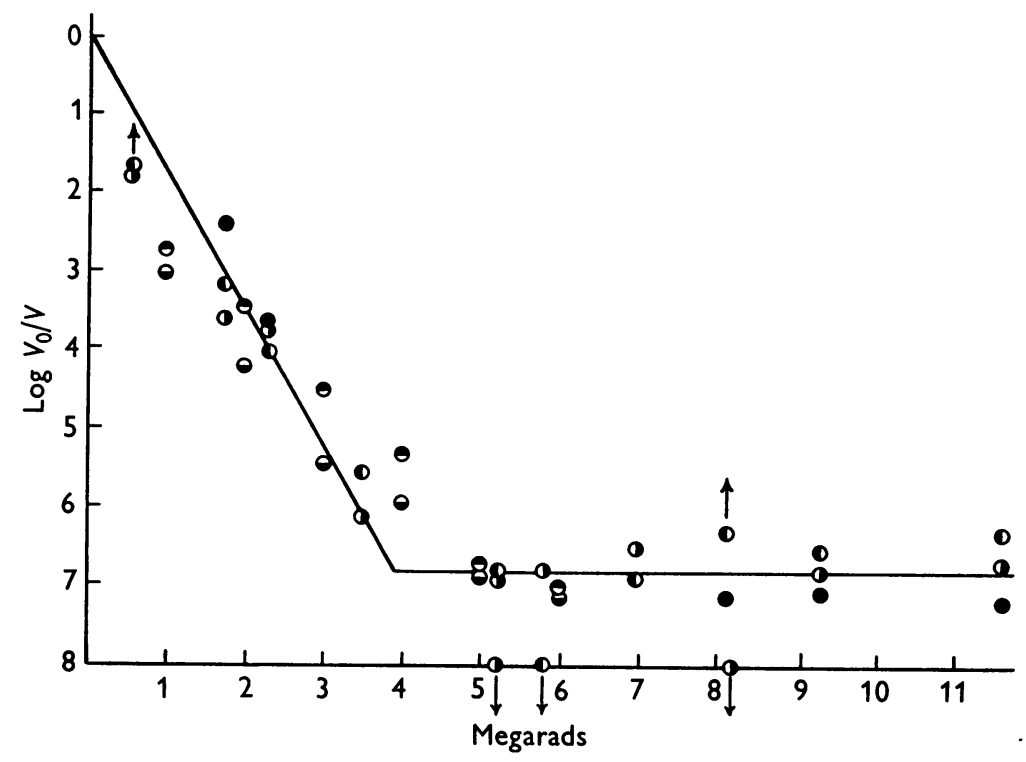

Fig. 1. Inactivation of dried vaccinia virus by $\gamma$-rays. $V_{0}=$ initial titre of virus. $V=$ titre at any specified radiation dose. 0 , Exp. no. $1 ; \log _{10} V_{0}=7 \cdot 15$. O, Expt. no. $2 ; \log _{10} V_{0}=7 \cdot 11$. $\odot$, Expt. no. $3 ; \log _{10} V_{0}=7 \cdot 48$. $\odot$, Expt. no. $4 ; \log _{10} V_{0}=$ 7.08. $\odot$, Expt. no. $5 ; \log _{10} V_{0}=8 \cdot 62$.

Table 4. Inactivation of vaccinia virus suspensions by $\gamma$-rays

Surviving virus (p.u./ml.)

$\begin{array}{lcc}\text { Mrad. } & \text { EBS 50/58 } & \text { EBS 57/58 } \\ 0 & 1 \cdot 1 \times 10^{7} & 1.2 \times 10^{7} \\ 0 \cdot 2 & 1 \cdot 6 \times 10^{4} & 7 \cdot 0 \times 10^{3} \\ 0 \cdot 4^{*} & 60(5) & 25(0) \\ 0 \cdot 6^{*} & 0(0) \dagger & 0(0) \dagger \\ 0 \cdot 8^{*} & \ddagger & 0(0) \dagger \\ 1 \cdot 0 & 0 & 0 \\ 1 \cdot 5 & \ddagger & 0\end{array}$

Each suspension divided into 7-12 ml. samples. One sample exposed at each irradiation dose.

* Inoculation repeated: second titre in brackets.

$\dagger$ Remainder of sample used for immunization of rabbits.

$\ddagger$ Not tested: bottles broke in transit.

$6 \times 10^{5}$ and $8 \times 10^{5} \mathrm{rad}$. (Table 4), were each used to immunize five rabbits. EBS 50/58 $\left(6 \times 10^{5} \mathrm{rad}\right.$.) induced both circulating antibody and resistance to challenge in the rabbits, whereas EBS $57 / 58\left(6 \times 10^{5}\right.$ and $8 \times 10^{5} \mathrm{rad}$.) induced only resistance to challenge 2 weeks after the second injection (Table 5), unequivocally 
raised titres of circulating antibody being absent. The sera from the animals used to test EBS $57 / 58\left(8 \times 10^{5} \mathrm{rad}\right.$.) contained no pock-inhibiting antibody.

As a confirmatory experiment, EBS 106/58 diluted to about $5 \times 10^{7}$ p.u. $/ \mathrm{ml}$.,

Table 5. Immunogenicity test of $\gamma$-irradiated vaccinia virus: resistance to challenge and circulating antibody

\begin{tabular}{|c|c|c|c|c|c|c|c|}
\hline \multirow[b]{2}{*}{ Inoculum } & \multirow{2}{*}{$\begin{array}{c}\text { Rabbit } \\
\text { no. }\end{array}$} & \multicolumn{5}{|c|}{ 5th day response to challenge virus diluted } & \multirow{2}{*}{$\begin{array}{l}\text { Neutralizing } \\
\text { antibody } \\
\text { titre }\end{array}$} \\
\hline & & $1 / 1000$ & $1 / 2000$ & $1 / 4000$ & $1 / 8000$ & $1 / 16,000$ & \\
\hline $\begin{array}{l}\text { EBS } 50 / 58 \\
6 \times 10^{5} \text { rad. }\end{array}$ & $\begin{array}{l}986 \\
987 \\
988 \\
989 \\
\mathbf{9 9 0}\end{array}$ & $\begin{array}{l}1 \mathrm{ab} \\
3 \\
1 \mathrm{ab} \\
1 \\
2\end{array}$ & $\begin{array}{l}1 \text { ab } \\
0 \\
0 \\
0 \\
0\end{array}$ & $\begin{array}{l}0 \\
0 \\
1 \text { ab } \\
0 \\
0\end{array}$ & $\begin{array}{l}0 \\
1 \\
0 \\
0 \\
0\end{array}$ & $\begin{array}{l}0 \\
0 \\
0 \\
0 \\
0\end{array}$ & $\begin{aligned} &> 1 / 64 \\
&>1 / 64 \\
& 1 / 32 \\
& 1 / 32 \\
& 1 / 8\end{aligned}$ \\
\hline $\begin{array}{l}\text { EBS } 57 / 58 \\
6 \times 10^{5} \mathrm{rad} .\end{array}$ & $\begin{array}{l}981 \\
982 \\
983 \\
984 \\
985\end{array}$ & $\begin{array}{l}\mathrm{sc}+, \mathrm{ab} \\
\mathrm{sc}+, \mathrm{ab} \\
\mathrm{c}, \mathrm{ab} \\
\mathrm{c}, \mathrm{ab} \\
8 \mathrm{ab}\end{array}$ & $\begin{array}{l}6 a b \\
9 a b \\
\text { sc, ab } \\
4 a b \\
0\end{array}$ & $\begin{array}{l}3 a b \\
2 a b \\
3 a b \\
1 a b \\
0\end{array}$ & $\begin{array}{l}4 a b \\
4 a b \\
0 \\
0 \\
0\end{array}$ & $\begin{array}{l}0 \\
0 \\
1 \text { ab } \\
0 \\
0\end{array}$ & $\begin{array}{r}<1 / 2 \\
<1 / 2 \\
1 / 4 \\
1 / 2 \\
<1 / 2\end{array}$ \\
\hline $\begin{array}{l}\text { EBS } 57 / 58 \\
8 \times 10^{5} \mathrm{rad} .\end{array}$ & $\begin{array}{l}\mathbf{9 7 6} \\
\mathbf{9 7 7} \\
\mathbf{9 7 8} \\
\mathbf{9 7 9} \\
\mathbf{9 8 0}\end{array}$ & \begin{tabular}{l}
\multicolumn{1}{c}{$\overline{a b}$} \\
$\mathrm{sc}+, \mathrm{ab}$ \\
$\mathrm{sc-,}, \mathrm{ab}$ \\
$2 \mathrm{ab}$
\end{tabular} & $\begin{array}{l}0 \\
0 \\
5 \mathrm{ab} \\
3 \mathrm{ab} \\
0\end{array}$ & $\begin{array}{l}-\overline{a b} \\
6 \mathrm{ab} \\
1 \mathrm{ab} \\
0\end{array}$ & $\begin{array}{l}-\overline{a b} \\
1 \mathrm{ab} \\
0 \\
0\end{array}$ & $\begin{array}{l}\overline{1 \mathrm{ab}} \\
1 \mathrm{ab} \\
1 \mathrm{ab} \\
0\end{array}$ & $\begin{array}{r}<1 / 2 \\
1 / 4 \\
1 / 2 \\
<1 / 2 \\
<1 / 2\end{array}$ \\
\hline
\end{tabular}

* Not challenged: killed after second bleed. $a b=$ abortive lesion, $c=$ confluent lesion, sc $+=$ semi-confluent lesion covering $70-80 \%$ of area, $\mathbf{s c}=$ semi-confluent lesion covering $50-70 \%$ of area, sc $-=$ semi-confluent lesion covering $<50 \%$ of area.

Table 6. Immunogenicity test of $\gamma$-irradiated vaccinia virus: resistance to challenge and circulating antibody

\begin{tabular}{|c|c|c|c|c|c|c|c|}
\hline \multirow[b]{2}{*}{ Inoculum } & \multirow{2}{*}{$\begin{array}{c}\text { Rabbit } \\
\text { no. }\end{array}$} & \multicolumn{4}{|c|}{$\begin{array}{c}\text { 5th day response to challenge } \\
\text { virus diluted }\end{array}$} & \multicolumn{2}{|r|}{ Neutralizing } \\
\hline & & $1 / 1000$ & $1 / 2000$ & $1 / 4000$ & $1 / 8000$ & $1 / 16,000$ & titre \\
\hline EBS $106 / 58$ & $26 / 58$ & 2 & $\mathbf{0}$ & $\mathbf{0}$ & 1 & $\mathbf{0}$ & $1 / 4$ \\
\hline \multirow[t]{4}{*}{$6 \times 10^{5} \mathrm{rad}$} & $27 / 58$ & 0 & 1 & 1 & $\mathbf{0}$ & $\mathbf{0}$ & $1 / 8$ \\
\hline & $28 / 58$ & $4 a b$ & $\mathbf{1}$ & 0 & $\mathbf{0}$ & $\mathbf{0}$ & $1 / 8$ \\
\hline & $29 / 58$ & $1 \mathrm{ab}$ & 0 & 0 & 0 & $\mathbf{0}$ & $1 / 8$ \\
\hline & $30 / 58$ & $2 a b$ & $1 \mathrm{ab}$ & $1 a b$ & 0 & $\mathbf{0}$ & $1 / 8$ \\
\hline EBS $106 / 58$ & $21 / 58$ & $1 \mathrm{ab}$ & 0 & $\mathbf{0}$ & 0 & 0 & $>1 / 16$ \\
\hline \multirow[t]{4}{*}{$8 \times 10^{5} \mathrm{rad}$} & $22 / 58$ & $3 a b$ & $5 \mathrm{ab}$ & 1 & $1 \mathrm{ab}$ & $1 \mathrm{ab}$ & $<1 / 2$ \\
\hline & $23 / 58$ & 5 & 4 & 1 & 0 & 2 & $<1 / 2$ \\
\hline & $24 / 58$ & $1 \mathrm{ab}$ & 0 & 0 & 0 & $\mathbf{0}$ & $1 / 8$ \\
\hline & $25 / 58$ & 7 & 3 & 1 & 6 & 2 & $<1 / 2$ \\
\hline
\end{tabular}

was sent for irradiation at two dose levels. Four bottles of virus suspension (c. $100 \mathrm{ml}$.) were to be exposed to $\gamma$-rays-two of them to $6 \times 10^{5} \mathrm{rad}$. and two to $8 \times 10^{5} \mathrm{rad}$. Unfortunately, one bottle received $9 \cdot 6 \times 10^{5} \mathrm{rad}$. instead of $8 \times 10^{5}$. After irradiation, the contents of similarly irradiated bottles were pooled and 
rabbits immunized with $11 \mathrm{ml}$. of each pool. The remainder of each pool was then concentrated by centrifugation to $1 \mathrm{ml}$., and the whole used to inoculate ten 12-day chorio-allantoic membranes; 2 days later, no pocks were found on any membrane. Five rabbits were inoculated with each of the preparations inactivated by 6 and $8 \times 10^{5} \mathrm{rad}$. (Table 6 ). Inactivation by $6 \times 10^{5} \mathrm{rad}$. left a virus with more immunogenic activity, measured both by resistance to challenge and circulating antibody response, than inactivation by $8 \times 10^{5} \mathrm{rad}$.

\section{DISCUSSION}

Pollard $(1953,1956)$ discusses the theoretical reasons for expecting inactivation by ionizing radiations to leave a high proportion of the surface antigens of a virus undamaged. On the assumption that protective antigenicity resides in the surface antigens, virus suspensions inactivated by ionizing radiations should make effective and easily prepared vaccines. Dick, Schwerdt, Huber, Sharpless \& Howe (1951) exposed suspensions of Type 2 poliomyelitis virus to a high-intensity electron beam. Doses of about $25 \times 10^{5}$ roentgen equivalents physical (r.e.p.) consistently inactivated infectivity and left reasonable antigenicity, whether the irradiation was done at atmospheric pressure or in vacuo at $-196^{\circ}$ or $-76^{\circ}$. Jordan \& Kempe (1956) inactivated mouse neurotropic vaccinia virus at $-76^{\circ}$ by $\gamma$-rays from a Co-60 source. Virus partially purified from infected mouse brain by differential centrifugation was more readily inactivated than unpurified suspensions, suggesting that in the crude preparations the impurities were protective, and that even at very low temperatures indirect radiation effects occurred. Exposure to $1.5 \times 10^{6}$ r.e.p. made the virus non-infectious by the tests used. Some antigenicity was retained. Traub, Friedemann, Brasch \& Huber (1951) bombarded suspensions of rabies virus with high-intensity electrons; they also inactivated infectivity while retaining antigenicity. They reported that the absorbed energy varied from 1.5 to $4.7 \times 10^{6}$ r.e.p.; it is, nevertheless, impossible to construct an inactivation curve from their results. The antigenicity of their vaccines varied within a 100-fold range, but there was no correlation between the inactivating dose of electrons and the antigenicity of the vaccines.

Judged by antibody response and tissue response to challenge in immunized animals, the immunogenicity of our inactivated preparations was not closely related to the inactivating dose of $\gamma$-rays (Table 5, EBS 50/58 and EBS 57/58). This may, perhaps, be associated with the fact that inactivation of suspensions must have been by a mixture of direct and indirect effects. A further point, shown very clearly in Table 6 , is that the response of immunized rabbits to skin challenge with a potent vaccinia virus preparation does not bear close relationship to the amount of circulating antibody. Little indeed is known of the quantitative relationships between circulating antibody and reaction to cutaneous challenge with vaccinia virus.

In our dried vaccine preparations indirect radiation effects were assumed to be negligible. Their absence may be expected to increase the dose of $\gamma$-rays necessary to inactivate completely, but cannot account for the survival of virus exposed to 
more than $10^{7} \mathrm{rad}$. The results of Jordan \& Kempe (1956), however, suggest that the peptone in the dried vaccine may have protected it. It may also be argued that this apparent survival was due to multiplicity reactivation. The phenomenon can be excluded on the following grounds: Cairns \& Fazekas de St Groth (1957) estimated the number of allantoic cells in the 12th-day chick embryo to be $4.25 \times 10^{5} / \mathrm{cm}^{2}$; Overman \& Tamm (1957) assumed that chorionic cells are at least three times as numerous as allantoic cells. The average area of chorioallantoic membrane available for inoculation on 25 consecutively treated embryos was $16 \mathrm{~cm} .{ }^{2}$, i.e. about $2 \times 10^{7}$ cells/dropped area. In an inoculum volume of $0.1 \mathrm{ml}$. the number of infectious units in un-irradiated vaccine would be about $10^{6} /$ membrane. The mean ratio of total particle count to infectious units for the virus strain used in these experiments is $c .12$ (Kaplan \& Valentine, 1959). There are, therefore, about $\left(12 \times 10^{6}\right) /\left(2 \times 10^{7}\right)=0.6$ particles/cell; so that multiplicity reactivation may be disregarded as a cause of pock formation by heavily irradiated vaccinia virus.

Although the physical arrangement of the dried virus in its ampoules precluded proper mathematical treatment of the results, it nevertheless seems that the inactivation of infectivity followed first-order (or pseudo first-order) kinetics until the proportion of survivors was very small. We do not think that the survival of this minute fraction of the virus has any bearing on the results of Lea \& Salaman (1942), nor on the general theory of sensitive volumes (Lea, 1955). Workers in the physical rather than the biological side of this field have, quite legitimately, seldom aimed at complete inactivation of their virus preparations. This is, of course, a necessary stage in the production of a safe vaccine.

In our opinion, the likeliest explanation of survival is that the virus is heterogeneous in its response to ionizing radiations as it is to heat (Kaplan, 1958), and to ultra-violet irradiation and $\beta$-propiolactone (unpublished observations). It was not possible, unfortunately, to determine experimentally whether the resistance to ionizing radiations was genetical. However, we have so far been unable to demonstrate a genetical basis for the heat-resistant fraction of vaccinia virus (Kaplan, 1958; and subsequent unpublished observations). It may be, therefore, that the resistant fraction of vaccinia virus is an expression of the heterogeneity of biological material in general.

\section{SUMMARY}

Suspensions and dried preparations of vaccinia virus were exposed to $\gamma$-rays in cobalt-60 sources. Suspensions completely inactivated by $6-8 \times 10^{5} \mathrm{rad}$. retained measurable immunogenicity. Dried preparations could not be completely inactivated even by doses of $11 \times 10^{6} \mathrm{rad}$., although the inactivation apparently followed first-order kinetics until about one particle in $10^{7}$ survived, suggesting that the populations of vaccinia virus in the preparations were heterogeneous.

I am indebted to Dr D. McClean for the titration of antibodies by rabbit scarification. 


\section{REFERENCES}

Boulter, E. A. (1957). J. Hyg., Camb., 55, 502.

CaIrNS, H. J. F. \& Fazeras De St Groth, S. (1957). J. Immunol. 78, 191.

Collier, L. H. (1955). J. Hyg., Camb., 53, 76.

Collier, L. H., McClean, D. \& Vallet, L. (1955). J. Hyg., Camb., 53, 513.

Dick, G. W. A., Schwerdt, C. E., Huber, W., Sharpless, C. R. \& Howe, H. A. (1951). Amer. J. Hyg. 53, 131.

Jordan, R. T. \& Kempe, L. L. (1956). Proc. Soc. exp. Biol., N.Y., 9, 212.

KaPLAN, C. (1958). J. gen. Microbiol. 18, 58.

Kaplan, C. \& Valentine, R. C. (1959). J. gen. Microbiol. 20, 612.

LEA, D. E. (1955). Actions of Radiations on Living Cells, ed. 2. Cambridge University Press.

Lea, D. E. \& Salaman, M. H. (1942). Brit. J. exp. Path. 23, 27.

Overman, J. R. \& TAMM, I. (1957). Virology, 3, 173.

Pollard, E. (1953). The Physics of Viruses. New York: Academic Press.

Pollard, E. (1956). Yale J. Biol. Med. 29, 436.

Traub, F. P., Friedemann, A. B., Brasch, A. \& Huber, W. (1951). J. Immunol. 67, 379.

Westwood, J. C. N., Phipps, P. H. \& Boulter, E. A. (1957). J. Hyg., Camb., 55, 123. 